\title{
Embedding graduate employability attributes in management sciences curricula: A case of two Namibian universities
}

\author{
Romanus Shivoro $^{1}$, Rakel Kavena Shalyefu ${ }^{1}$ and Ngepathimo Kadhila ${ }^{1}$ \\ rshivoro@gmail.com; rkshalyefu@unam.na; nkadhila@unam.na \\ ${ }^{1}$ University of Namibia
}

\begin{abstract}
Recognising implicit employability attributes within discipline-specific program modules is a critical part of the process of developing new employability modules in the management sciences curricula. The notion of graduate employability has gained acceptance in the higher education sector across the world and furthermore higher education and industry appear to have reached consensus on the importance of enhancing graduate attributes through the curricula at university. This paper offers a qualitative analysis of curricula documents to determine strategies that are effective in enhancing graduate employability. Using content analysis to assess six bachelor degree programs in management sciences from selected universities in Namibia, the study established that, in addition to work-integrated learning modules, there is evidence of graduate employability attributes being implicitly embedded in core curricula and discipline-specific modules. The researchers argue that universities should develop a stand-alone core module specifically to cultivate employability attributes. This should be supported by multiple workintegrated learning experiences for students to practise technical or discipline specific skills and generic employability attributes.
\end{abstract}

Key words: employability attributes, content analysis, implicit employability, graduate attributes, work-integrated learning

\section{Introduction}

The notion of enhancing graduate employability through curriculum provision has gained prominence in the higher education sector across the world. Higher education institutions (HEls), employers and graduates are in agreement that graduates need other attributes in addition to subject-specific discipline knowledge (Andrews \& Higson, 2008; Weligamage, 2009). As a result, universities are placed under pressure by the labour market to demonstrate that they are effectively and efficiently equipping students with employability attributes to meet the demands of the $21^{\text {st }}$ century (Barrie, 2006). In Namibia, the labour market has expressed concerns about graduates' readiness for the world of work (Links, 2010; Schade \& Amunkete, 2011). Specifically, employers claim that graduates from HEls in Namibia do not all possess the types of graduate employability attributes necessary for employment. In addition, Namibia's National Council for 
Higher Education (2011) has claimed that graduates are not adequately prepared for work, and that their training is not relevant to the demands of the work place. This sentiment is echoed by Kanyenze (2012), who argues that there is a mismatch between skills demanded and skills provided, and a lack of coordination between producers of knowledge and users of skills in Namibia.

To date, research on graduate employability has produced varied lists of employability attributes required in the contemporary workforce (Markes, 2006). Rosenberg, Heimler and Morote (2012) synthesised these attributes into eight categories: literacy and numeracy, interpersonal attributes, work ethic, leadership attributes, information technology, critical thinking, systems thinking, and management attributes. The task at hand for higher education is to determine the best strategies for effective and efficient delivery of these attributes to students.

Despite the labour market's expectation that higher education will demonstrate how to enhance graduate employability, there seems to be no agreement as to which approach would provide sufficient opportunities to enhance the required attributes. Yorke and Knight (2006) suggest that employability can be fostered through a range of curriculum levels. They further assert that one size does not fit all institutions and/or disciplines as far as employability is concerned.

The aim of this paper is therefore to analyse how employability attributes have been incorporated into the curricula of management sciences, using two Namibian universities as a case study, and to assess which approach might be the best in fostering graduate employability. The argument presented here is that universities should develop a stand-alone core module on graduate employability. This module should be supported by work-integrated learning at different stages of the curriculum.

\section{Strategies for enhancing employability attributes in higher education}

The sole purpose of teaching graduate attributes is to enhance graduates' skill sets in order to enhance their work-related skills (Sarkar, Overton, Thompson, \& Rayner, 2016) and thereby boost their competitiveness in the job market (Jonck, 2014; Mason, Williams, \& Cranmer, 2009). Several researchers have voiced opinions on strategies that might enhance graduate employability. For example, Saunders and Zuzel (2010) established that the current trend of enhancing graduate employability is to incorporate opportunities for employability skills alongside subject-specific knowledge and skills. This means that the program of study is separate from graduate employability interventions. In contrast to this strategy, Mason et al. (2009) and Bhola and Dhanawade (2013) observe that some universities have adopted the strategy of integrating graduate employability into programs of study. Here, employability is built into the program, alongside the specific learning outcomes of the degree. These strategies include offering work experience, work-related learning and employability skills modules, and 'ready for work' events, as well as involving employers in course design and delivery. This is a rather general view of possible employability enhancing opportunities, without elaborating on the specific details of the benefits to either academics or students who are participating in these experiences.

Authors such as Jackson (2014), Pillai, Khan, Syahirah and Raphael (2012) and Gardner (1998) have suggested that, in their efforts to create opportunities for enhancing students' workplace readiness, academic staff should highlight opportunities to develop graduate employability attributes in their courses, rather than regarding skills classes as single, one-off experiences. In addition, they should be more involved in experiential programs such as providing opportunities for student reflection on experiences, and should set rigorous standards and evaluation criteria for internships/work-based placements. Furthermore, academics should seek to engage students in contextual situations (for example, community projects). Such an approach would encourage students to reflect on their experiences, skills acquisition and application of education or academic

Shivoro, R., Shalyefu, R., \& Kadhila, N. (2017). Embedding graduate employability attributes in management sciences curricula: A case of two Namibian universities. Journal of Teaching and Learning for Graduate Employability, 8(1), 123-136. 
training to future work and life situations. This suggests that employability should be built into an existing module or course so that the skills are contextualised. This aspect calls for a rigorous engagement between student and lecturer while students are on internship placements. It also requires that academics follow the students to the workplace. Gardner (1998) argues that the challenge is to incorporate such opportunities in incremental stages in the intellectual, professional and personal development of university students.

\section{Levels at which graduate employability could be embedded in the curriculum}

Work on embedding employability attributes within the curriculum was initiated by Yorke and Knight (2006). They suggested five levels at which employability could be fostered in the curriculum, either explicitly or implicitly. The first level is employability throughout the entire curriculum. At this level, each student is required to demonstrate eight broad abilities at progressively more complex levels in both general education and the specialist subject(s) chosen. These abilities are: communication (reading, writing, speaking, listening, and visual, quantitative, and technological skills), analysis, problem solving, decision-making, social interaction, global perspectives, effective leadership, and aesthetic responsiveness. Here, subject understanding is blended with skillful operational practices. Owens and Tibby (2014) provide the example of the Staffordshire Graduate Employability Project (SGEP), a university-wide undergraduate program on employability focusing on attributes such as discipline expertise, professionalism and professional integrity, global citizenship, communication and teamwork, reflective and critical learning, and lifelong learning. These attributes are embedded in the whole curriculum, with a clear acknowledgement of the need for preparation for employability to be central to all programs and courses.

The second level is employability in the core curriculum: a university may opt to designate a module or two as vehicles for the development of employability attributes. Kemp (2009) studied the case of a module that was designed to enhance employability and provided evidence for the possibility of developing an employability profile that focuses on enhancing specific practical experience using a single module, while at the same time strengthening basic employability attributes. Another case is provided by Jackson (2013), who discussed a learning module dedicated to developing employability skills in a business context. The module had four units that were core to the Bachelor of Business program. In this example, each of the four units aimed to enable students to acquire a variety of employability skills through practical experience in a business context.

The third level occurs when work-based or work-related learning is interspersed throughout the curriculum. This model is regarded as a contributor to employability. This includes placements of various periods, ranging from short periods to one-year placements. Research has provided evidence of greater self-confidence and awareness of the challenges to be faced in the world of work as a result of such placements. Students are required to complete a period of work experience and produce a report for both the workplace and the academic tutor. Many universities credit work-based learning as part of their curricula. An example of this level is provided by Pillai et al. (2012) in their discussion of an industrial training program at the University of Malaya in Malaysia. Students received feedback sessions with lecturers and workplace training providers on skills gaps and mismatches in the workplace, as well as receiving continuous input from the workplace. In such a model, effective collaboration between academic staff and practitioners supervising students at work, is essential. Kettis, Ring, Gustavsson and Wallman (2013) suggest that interaction by higher education institutions with employers through placements enriches both parties, that is, academic staff at university and supervisors of students at placements. Academic staff gain insight into practice, which may inspire teaching on campus, for instance by generating real life examples that trigger students' motivation and inform curriculum design.

Shivoro, R., Shalyefu, R., \& Kadhila, N. (2017). Embedding graduate employability attributes in management sciences curricula: A case of two Namibian universities. Journal of Teaching and Learning for Graduate Employability, 8(1), 123-136. 
At the fourth level, employability-related modules are situated within the curriculum. These modules develop the students' skills at the beginning of their program of study as they focus on freestanding skills. These modules are based on the assumption that if students are able to develop their personal autonomy in studying at the beginning of their studies, this will have longterm benefits. At this level, the university may develop a suite of modules designed to engage first-year students in a learning experience aimed at equipping them with the skills needed to meet the challenges of creativity and innovation (Quality Assurance Agency for Higher Education, 2009).

The final level is work-based or work-related learning in parallel with the curriculum. This occurs when students are employed part-time while they are studying. Part-time employment could provide an experiential base for the academic study of employment-related disciplines. Tran (2016) notes that this is a form of university-enterprise collaboration or partnership that involves work-based learning degree programs/sandwich courses. This kind of partnership blurs the barriers between the academic world and the world of work. Muldoon (2009) presents a case study of the outcomes of an institutional award for the development of graduate employability attributes. In the study, students engaged in paid and voluntary part-time work as professional development and extra-curricular activity. The study concluded that part-time work was a useful avenue for the development of graduate employability attributes.

Nagarajan and Edwards (2014) caution that higher education institutions may face a challenge in their efforts to integrate graduate employability attributes in their curricula. This challenge is posed by the different conceptualisations of graduate employability at various institutional levels such as university, faculty, school, department, program of study and particular subjects. One approach to managing the different levels is the use of overarching generic attributes that can then be broken down into specifics which can be implemented at lower levels. Subsequently, these attributes are transformed by the faculty into a set of more specific learning goals relevant to the particular degree. The successful development of graduate employability attributes can then be facilitated by aligning learning design, learning outcomes, teaching and learning activities and assessment criteria and tasks with the generic attributes.

The overview presented above provides this paper with a framework with which to analyse and assess strategies and levels at which employability attributes have been incorporated into the curricula of management sciences in Namibia. The study asked the following question: How is graduate employability embedded in management sciences bachelor degree curricula in Namibia? Using the results from the first question, the paper then assesses which strategy can be considered most effective in enhancing graduate employability in curricula.

\section{Methodological approach}

This study employed a qualitative approach using content analysis as a method to determine which strategy was most effective in integrating graduate employability into management sciences curricula (Creswell, 2003). The sample comprised curriculum documents from six undergraduate degree programs at two public universities in Namibia. Three degree programs from each university, namely, Bachelor of Business Management/Administration, Bachelor of Accounting (general), and Bachelor of Economics were studied. These were four-year degree programs and were common to both institutions, thus allowing for comparisons of strategies employed in a similar program at two different institutions operating in the same context. In the interests of confidentiality as a principle of research ethics, the two universities that were the focus of the study are referred to as University A and University B. The researchers used the content analysis to identify explicit and implicit graduate employability attributes throughout the degree programs. This was done using both deductive and inductive methods of content analysis (Zhang \& Wildemuth, 2009). Qualitative analysis software, Atlas ti. Version 7.1.4., was used to code

Shivoro, R., Shalyefu, R., \& Kadhila, N. (2017). Embedding graduate employability attributes in management sciences curricula: A case of two Namibian universities. Journal of Teaching and Learning for Graduate Employability, 8(1), 123-136. 
portions of content from the curriculum documents and categorise these according to strategies and levels presented in the literature (see Figure 1).

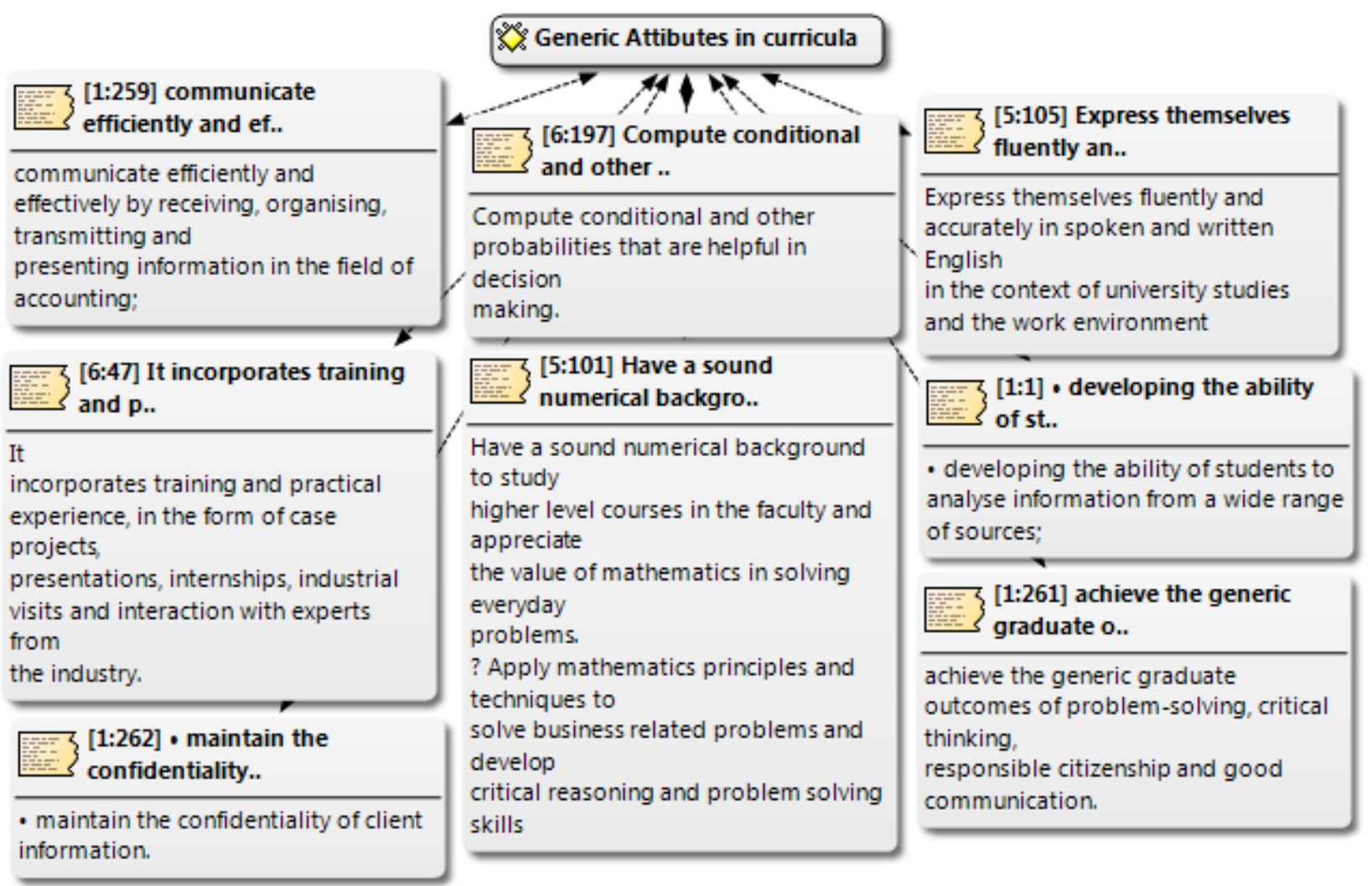

Figure 1: An Example of Coding Portions of Content for Analysis using Atlas ti. Version 7.1.4.

\section{Results and discussion}

Results of the analysis are categorised using the levels and strategies of embedding graduate employability into curricula that are presented in the literature. The hierarchy begins with assessing whether the broad aims of the program make reference to graduate employability: the terms generally used are employability skills or attributes, transferable skills, generic attributes, graduate attributes, and soft skills. A university would have agreed on particular attributes to concentrate on based on demand from the labour market. This indicates the intention and commitment of the university to equip students with employability attributes, and these become known to students, academics and industry.

\section{Level 1: Employability-related modules in the whole curriculum}

This level analysed whether the two universities have purposefully incorporated graduate employability attributes in the aims of the programs. Below, in Table 1, are excerpts from the program documents. 
Table 1: Broad Program Aims in Relation to Graduate Employability

\begin{tabular}{l} 
UNIVERSITY A \\
\hline Program 1: \\
Students will have the opportunity to develop \\
the required cognitive/intellectual, practical \\
and key transferable skills, and apply these to \\
complex accounting issues in the context of an \\
organization.
\end{tabular}

\section{Program 2:}

The program will enable students to acquire cognitive, practical problem-solving, and key transferable skills that are necessary for addressing pressing challenges in the current Namibian market and economy.

\section{Program 3:}

The program will enable students to acquire cognitive/intellectual, practical and key transferable skills and to apply these skills in solving economic problems that face the public and private sectors, as well as the overall economy.

\section{UNIVERSITY B}

\section{Program 1:}

The purpose of this qualification is to provide an academic foundation for students intending to pursue a career in the accounting profession or financial service sector.

\section{Program 2:}

This qualification equips students with intellectual ability, executive personality and managerial skills through an appropriate blending of business and general education.

\section{Program 3:}

The purpose of this qualification is to produce graduates who are technically and intellectually competent in the application of economic theories, models and techniques.

Data analyses indicated that in all three degree programs, University A articulated that graduate employability would be enhanced in the program. A broad statement is made in the aims section of each degree program. Specifically, each program asserts that students will have the opportunity to develop key transferrable skills and will be able to apply these to address challenges. This is done alongside the technical or discipline related aims of the degree program. However, this is not the case in the aims of programs at University B, where no reference is made to enhancing graduate employability attributes in the broad aims of Programs 1 and 3 . The broad aim of Program 2 makes reference to developing executive personality. The broad program aims are further expanded into specific aims in the curriculum documents, as indicated in Table 2. 
Table 2: Specific Program Aims in Relation to Graduate Employability Attributes

\begin{tabular}{|c|c|}
\hline UNIVERSITY A & UNIVERSITY B \\
\hline & Program 1: \\
\hline $\begin{array}{l}\text { Developing the ability of students to analyse } \\
\text { information from a wide range of sources; } \\
\text { equipping students with the requisite skills to } \\
\text { work effectively as individuals and as } \\
\text { members of a team; enabling students to } \\
\text { communicate effectively in the workplace. }\end{array}$ & $\begin{array}{l}\text { This qualification equips students with the } \\
\text { necessary accounting knowledge and skills } \\
\text { that allow them to pursue their career in } \\
\text { accounting, auditing, finance, taxation, } \\
\text { banking and other related areas to contribute } \\
\text { towards nation building and realisation of } \\
\text { Vision } 2030 \text {. }\end{array}$ \\
\hline
\end{tabular}

\section{Program 2:}

Developing the ability of students to collect, analyse and interpret information from a variety of sources; preparing students to add value in the workplace through individual endeavour, as well as within a team context; and developing the generic as well as business communication skills of students.

\section{Program 3:}

Developing the ability of students to analyse information from a wide range of sources; equipping students with the requisite skills to work effectively as individuals and as members of teams, and enabling students to communicate effectively in the workplace.

\section{Program 2:}

It is meant to develop the student's practical managerial skills, communication skills and business decision-making capability. It incorporates training and practical experience in the form of case projects, presentations, internships, industrial visits and interaction with experts from the industry.

\section{Program 3:}

The qualification will sharpen the students' analytical skills through integrating their knowledge of economic theory with real life economic issues encountered in day to day economic decision-making processes, both in the government and private sector.

Curriculum documents from University A highlight specific graduate attributes as outcomes of its programs. These attributes are: skills to work effectively as individuals and as team members; ability to communicate effectively in the workplace; and analysing information from a variety of sources. These appear in the intended outcomes of all three degree programs. In contrast, Program 1 of University B does not make reference to graduate employability attributes other than discipline-specific knowledge and skills. Programs 2 and 3 make reference to practical projects, internships, industrial visits, and the integration of theory with real life issues. There seems to be no consistency in the intent to develop graduate employability attributes in University B programs.

Despite the overarching statement concerning transferable skills and a second tier of attributes in University A's programs, it was clear that there was a third tier of attributes that was unique to a given degree program. All three programs from University A have the uniform outcome that students will achieve the generic graduate outcomes of problem-solving, critical thinking, responsible citizenship and good communication. However, Program 1 indicates the additional outcomes of: display honesty (integrity), social responsibility (consideration of the public interest), competence, objectivity and professional demeanour by their timeliness, due care, courteousness, respect, responsible actions and reliability. A comparison with University B shows

Shivoro, R., Shalyefu, R., \& Kadhila, N. (2017). Embedding graduate employability attributes in management sciences curricula: A case of two Namibian universities. Journal of Teaching and Learning for Graduate Employability, 8(1), 123-136. 
that its Program 2 notes that graduates will be able to apply innovation and creativity skills in a business environment and communicate effectively in a business environment. Program 3 from University B states that graduates should achieve quantitative and qualitative analysis and critical thinking skills as outcomes. Program 1 from University B makes no mention of generic attribute outcomes. This does not mean that there are no graduate employability attributes embedded in the University B Programs, however, they are not made explicit but implied, as will be shown later in this section.

\section{Level 2: Employability in the core curricula}

Analysis has indicated that at both University A and University B, certain modules form part of the core curricula; these are compulsory for all students undertaking the degree program. The modules focus on communication skills, information technology skills and responsible citizenship. At both universities, the modules are delivered through contact hours, directed self-learning, and self-directed learning; and are assessed by continuous assessment and exams at the end of the semester. In addition, it was observed that some employability modules in the core curricula of management sciences at University A had incremental stages of competence. For example, there are three modules aimed at enhancing communication skills in a single degree program. Below is a depiction of employability modules with incremental stages of competency.

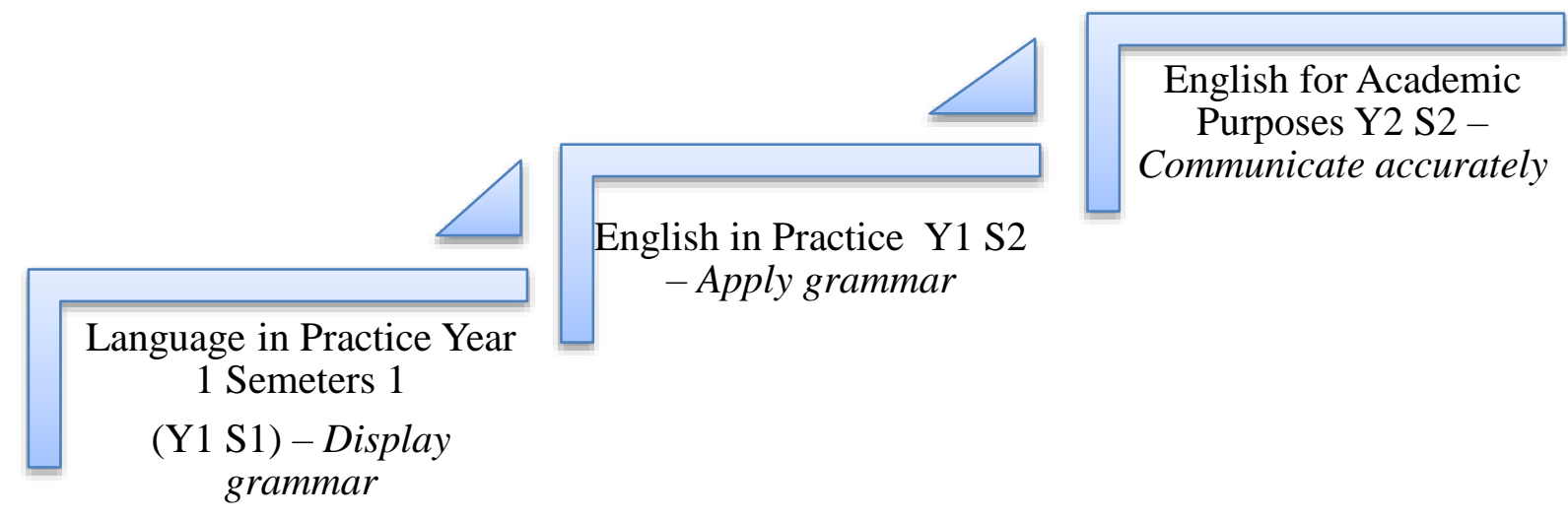

Figure 1: Incremental Stages of English Competency

A second graduate employability provision with incremental stages is aimed at enhancing information technology. Below is a depiction of the incremental stages of competence.

Information Competence, Y1 S1 - Search for information using search engines on the Internet and Web 2.0 technologies to solve given problems and critically evaluate information obtained.

Computer User Skills, Y2 S2 - apply various technical and practical skills to use basic functions of the personal computer, as well as widely used application software, to solve problems and improve personal and organizational productivity.

Figure 2: Incremental Stages of Information Technology Competency 
At University B, all management sciences programs have common modules as part of the core curricula. These modules are: Computer Literacy, English Communication and Study Skills, English for Academic Purposes, Contemporary Social Issues, and Business Mathematics. As at University A, the English courses at University B are incremental. This is also the case in a University B module Business Mathematics, which prepares students for other mathematical and statistical modules at higher levels of the degree. This means that although the core curriculum serves as a foundation to prepare students for subsequent advanced levels of learning, these modules provide an implicit opportunity to develop generic employability attributes at the same time. These universities should determine whether core modules are to be considered as employability modules in core curricula.

\section{Level 3: Work-based or work related learning}

A module entitled Work Integrated Learning (WIL) is offered in all degree programs at University A. It is compulsory for all students registered for any of the degrees. The program is offered during the first semester of the third year of the degree. Students are eligible to register for this module if they have passed all the modules in their first and second years. The WIL module enables students to evaluate, apply and practise learnt competencies in the workplace to improve career prospects. It provides an opportunity for firsthand work experience in the student's field of study and focuses on both discipline specific skills and employability attributes. The following is an excerpt from Program 1 from University A:

Enabling students to apply various accounting and finance-related theories/best practices to real world accounting and finance situations/problems; developing capabilities such as effective oral and written communication, teamwork, planning and organising, thinking creatively and problem solving; enabling students to acquire general work experience and work ethics, and to manage time, communicate effectively, make presentations and apply economic theory to the various workplace tasks.

The WIL module is assessed through students' workplace experience reports, the academic supervisor's workplace visitation report, workplace supervisors' reports, and students' presentation skills. Although University B's Program 2 mentions internships as part of the degree offering, there is no specific module related to internship in any of the three management sciences programs at this university.

The WIL experience at University A is offered in Semester 1 of Year 3; this implies that students are practising the theory they have learned in the first two years of the degree program. Here, employability is embedded at the mid-point of the degree program. As learning is incremental, students enter the workplace with basic knowledge and skills learnt in the study program. Therefore, it is important for universities to determine the best moment within the program to offer and assess WIL so that students have the opportunity to undergo workplace experience of the theoretical learning acquired in years 3 and 4.

Level 4: Other modules enhancing discipline-contextualised attributes related to graduate employability

In the analysis of modules that embed graduate employability in curricula, the following modules were identified by the characteristics of their outcomes, which were related to specific employability attributes. These modules are contextualised to business management, but they also have characteristics of graduate employability. Table 3 provides descriptions, taken from the curriculum documents, of these characteristics.

Shivoro, R., Shalyefu, R., \& Kadhila, N. (2017). Embedding graduate employability attributes in management sciences curricula: A 
Table 3: Discipline-specific Modules with Graduate Employability Attribute Characteristics

\begin{tabular}{l|l|c}
\hline \multicolumn{1}{c|}{ Module } & \multicolumn{1}{|c}{ Aim - the module enables students to: } & $\begin{array}{c}\text { Year and } \\
\text { Semester }\end{array}$ \\
\hline Systems Thinking & $\begin{array}{l}\text { Apply knowledge of systems thinking to improve } \\
\text { decision-making in the business administration } \\
\text { and management domain. }\end{array}$ & $\begin{array}{c}\text { Y2 S1 } \\
\text { (University A) }\end{array}$ \\
\hline Business Ethics & $\begin{array}{l}\text { Analyse and apply general ethical concepts in } \\
\text { making ethical decisions in a business } \\
\text { environment. }\end{array}$ & $\begin{array}{c}\text { Y2 S2 } \\
\text { (University A) }\end{array}$ \\
\hline $\begin{array}{l}\text { Innovation, } \\
\text { Creativity \& } \\
\text { Entrepreneurship }\end{array}$ & $\begin{array}{l}\text { Create innovative and feasible business ideas and } \\
\text { develop a comprehensive and functional business } \\
\text { plan for a sustainable entrepreneurial business. }\end{array}$ & $\begin{array}{c}\text { Y3 S1 } \\
\text { (University A) }\end{array}$ \\
\hline $\begin{array}{l}\text { Business Ethics \& } \\
\text { Leadership }\end{array}$ & $\begin{array}{l}\text { Analyse and apply general ethical concepts in } \\
\text { making ethical decisions in a business } \\
\text { environment. }\end{array}$ & $\begin{array}{c}\text { Y1 S2 } \\
\text { (University A) }\end{array}$ \\
\hline $\begin{array}{l}\text { Business Research } \\
\text { Methods }\end{array}$ & $\begin{array}{l}\text { Select a research problem, define it, do the } \\
\text { preliminary literature review and develop research } \\
\text { design for problem solving. } \\
\text { Collect suitable data using appropriate methods } \\
\text { and perform data analysis. }\end{array}$ & $\begin{array}{c}\text { Y3 S2 } \\
\text { (University B) }\end{array}$ \\
\hline Research Project & $\begin{array}{l}\text { Formulate a research topic and research } \\
\text { questions, then undertake a literature study. } \\
\text { Write a research proposal, collect and analyse } \\
\text { relevant data and develop a written report. }\end{array}$ & $\begin{array}{c}\text { Y4 S1 } \\
\text { (University B) }\end{array}$ \\
\hline
\end{tabular}

The topics and aims of these modules indicate strong elements of graduate employability attributes. For example, if the term business administration is excluded from the aim of the Systems Thinking module, the aim will read as: Apply knowledge of systems thinking to improve decision-making. Another example from the Business Ethics module is Analyse and apply general ethical concepts in making ethical decisions. These examples suggest that graduate employability has a strong presence within these modules. Thus they are implicitly enhancing generic attributes required in the workplace.

Implicit graduate employability attributes in curricula

Despite a lack of statements specifically intended to develop graduate employability attributes in some University B management sciences programs, further analyses of curriculum documents have established that graduate employability attributes are implicitly embedded in all University B programs. Below are examples of excerpts from curriculum documents.

- Numeracy and critical thinking: Apply mathematics principles and techniques to solve business related problems and develop critical reasoning and problem solving skills. 
- Communication skills: Express themselves fluently and concisely in spoken and written English in the context of university studies and the work environment.

- Problem solving: Apply the knowledge acquired for solving the real life problems using techniques such as linear programming, network analysis.

- ICT skills: Apply practical computer skills to use relevant software effectively, including Microsoft Windows, Microsoft Word, Microsoft Excel and Microsoft PowerPoint.

- Innovation and creativity: Prepare bankable business plans, apply innovation and creativity skills in a business environment.

- Ethics: Demonstrate critical knowledge of diversity and ethics.

- Management skills: Apply conflict management and conflict resolution skills in organisations.

- Leadership skills: Demonstrate a sound knowledge of strategic leadership.

From the examples above, it can be concluded that there is an assumption of work-related training in the programs. Specifically, there are elements of work-integrated learning through which students are expected to apply acquired knowledge and skills. However, there is no specific reference to prearranged work-integrated learning experiences.

\section{Conclusion}

This paper analysed levels and strategies through which graduate employability has been embedded in the curricula of management sciences, using Namibian universities as a case study. It then assessed which approach was most ideal for embedding graduate employability in the curricula. Graduate employability has been defined in the literature as the qualities, skills, knowledge and abilities of university graduates, beyond disciplinary content knowledge, which are applicable to a range of contexts and are acquired as the result of completing any undergraduate degree, and which should represent the core achievements of a university education (Barrie, 2006; Yorke \& Knight, 2006).

Using the above explanation, the study found that employability attributes are explicitly but, largely, more implicitly embedded in the whole curriculum. Although desirable, an absence of a principal statement on developing graduate employability in program aims may not necessarily imply an absence of opportunities for developing employability attributes in such a program. Core modules in curricula have a dual role to provide a foundation to university education and to act as vehicles for developing graduate employability attributes. Skills related to numeracy, communication, information and communication technology were found to be largely embedded in core curriculum modules. Discipline-specific modules may also be a valuable resource for enhancing graduate employability attributes. Specifically, skills related to leadership, management, innovation and creativity, critical thinking, and ethical conduct were found to be embedded in discipline-specific modules.

As is evident from the analysis, work-integrated learning provides an opportunity for students to practise discipline-specific skills, but it also serves as a professional space for students to learn and practise generic or transferrable attributes. This is particularly useful in developing generic attributes when the workplace learning experience is arranged during the early years of the degree program. If workplace learning takes place during the final year of the degree, the student might be in position to showcase and practise advanced discipline-specific knowledge and skills,

Shivoro, R., Shalyefu, R., \& Kadhila, N. (2017). Embedding graduate employability attributes in management sciences curricula: A case of two Namibian universities. Journal of Teaching and Learning for Graduate Employability, 8(1), 123-136. 
coupled with employability attributes. Therefore, a university should determine specific learning outcomes of any work-integrated learning experience.

The study revealed the extent of graduate employability outcomes embedded in discipline-specific modules with specific outcomes related to graduate employability also being identified. Both discipline-specific modules and employability modules specifically intended to enhance graduate employability were interlinked, and both were valuable in the development of graduate attributes.

The study concludes that the best strategy to integrate employability attributes in curricula is to develop a graduate employability module as a core module. Such a module should indicate the specific attributes that the university is intending to enhance. This should be supported by continuous workplace learning opportunities and reflection activities so that students can continuously reflect on their experiences and relate theoretical learning, from the earliest to the most advanced stage of the degree. However, universities should first take stock of those graduate employability attributes that are implicitly embedded in discipline-specific modules, and build on these by developing explicit employability modules. Further research should determine the best stage in the curriculum at which to effectively enhance and assess graduate employability. 


\section{References}

Andrews, J., \& Higson, H. (2008). Graduate employability 'soft skills' versus 'hard' business knowledge: A European study. Higher Education in Europe, 33(4), 411-422. https://doi.org/10.1080/03797720802522627

Barrie, S. C. (2006). Understanding what we mean by the generic attributes of graduates. Higher Education, 51(2), 215-241.

Bhola, S. S., \& Dhanawade, S. S. (2013). Higher education and employability-A review. Pravara Management Review, 11(1) 45-54. https://doi.org/10.2139/ssrn.2290103

Creswell, J. W. (2003). Research design: Quantitative, qualitative and mixed methods approaches (2nd ed.). London: Sage Publications. Retrieved from https://isites.harvard.edu/fs/docs/icb.topic1334586.files/2003_Creswell_A Framework for Design.pdf

Gardner, P. (1998). Are college seniors prepared for work? In J.N. Gardner \& G. Van der Veer (Eds.), The senior year experience. Facilitating integration, reflection, closure, and transition, (pp. 60-78). San Francisco: Jossey-Bass Inc Publishers.

Jackson, D. (2013). Student perceptions of the importance of employability skill provision in business undergraduate programs. Journal of Education for Business, 88(5), 271-279.

Jackson, D. (2014). Modelling graduate skill transfer from university to the workplace. Journal of Education and Work, 29(2), 199-231. https://doi.org/10.1080/13639080.2014.907486

Jonck, P. (2014). A human capital evaluation of graduates from the Faculty of Management Sciences employability skills in South Africa. Academic Journal of Interdisciplinary Studies, 3(6), 265-274. https://doi.org/10.5901/ajis.2014.v3n6p265

Kanyenze, G. (2012). Growth, employment and decent work in Namibia: A situation analysis, WP no.81. Geneva: ILO.

Kemp, S. (2009). Embedding employability and employer engagement into postgraduate teaching: A case study from 'environmental management systems'. Planet, 21(1), 47-52.

Kettis, A., Ring, L., Gustavsson, M., \& Wallman, A. (2013). Placements : An underused vehicle for quality enhancement in higher education? Quality in Higher Education, 19(1), 28-40.

Links, F. (2010). Namibia's skills deficits: Cross-sectoral perceptions and experiences. Windhoek: Namibia Employers Federation.

Markes, I. (2006). A review of literature on employability skill needs inengineering. European Journal of Engineering Education, 31(6), 637-650.

Mason, G., Williams, G., \& Cranmer, S. (2009). Employability skills initiatives in higher education: What effects do they have on graduate labour market outcomes? Education Economics, 17(1), 1-30. https://doi.org/10.1080/09645290802028315

Muldoon, R. (2009). Recognizing the enhancement of graduate attributes and employability through part-time work while at university. Active Learning in Higher Education, 10(3), 237252. https://doi.org/10.1177/1469787409343189

Nagarajan, S., \& Edwards, J. (2014). Is the graduate attributes approach sufficient to develop work ready graduates? Journal of Teaching and Learning for Graduate Employability, 5(1), 12-28.

National Council for Higher Education. (2011). Tracer study of graduates from higher education Institutions 1999-2008. International Network of Graduate Surveys.

Shivoro, R., Shalyefu, R., \& Kadhila, N. (2017). Embedding graduate employability attributes in management sciences curricula: A 
Owens, J., \& Tibby, M. (2014). Enhancing employability through enterprise education: Examples of good practice in higher education. UK: The Higher education Academy.

Pillai, S., Khan, M. H., Syahirah, I., \& Raphael, S. (2012). Enhancing employability through industrial training in the Malaysian context. Higher Education, 63, 187-204. https://doi.org/10.1007/s10734-011-9430-2

Quality Assurance Agency for Higher Education. (2009). Learning from ELIR 2003-07. Emerging approaches to employability and personal development planning: Sharing good practice. Mansfield: QAA.

Rosenberg, S., Heimler, R., \& Morote, E.-S. (2012). Basic employability skills: A triangular design approach. Education + Training, 54(1), 7-20. https://doi.org/10.1108/00400911211198869

Sarkar, M., Overton, T., Thompson, C., \& Rayner, G. (2016). Graduate employability: Views of recent science graduates and employers. International Journal of Innovation in Science and Mathematics Education, 24(3), 31-48.

Saunders, V., \& Zuzel, K. (2010). Evaluating employability skills: Employer and student perceptions. Bioscience Education, 15(2), 1-15.

Schade, B. K., \& Amunkete, T. (2011). Democracy Report: Namibia Labour Force Survey 2008. Windhoek: Institute for Public Policy Research.

Tran, T. T. (2016). Enhancing graduate employability and the need for university-enterprise collaboration. Journal of Teaching and Learning for Graduate Employability, 7(1), 58-71. https://doi.org/10.21153/jtlge2016vol7no1art598

Weligamage, S. S. (2009). Graduates' employability skills : Evidence from literature review. Sri Lanka:University of Kelaniya. Accessed at: http://www.kln.ac.lk/uokr/ASAIHL/SubThemeA8.pdf

Yorke, M., \& Knight, P. (2006). Employability: Embedding employability into the curriculum. Learning and Employability. Heslington, UK: The Higher Education Academy.

Zhang, Y., \& Wildemuth, B. (2009). Qualitative analysis of content. In B. Wildemuth (Ed.), Applications of social research methods to questions in Information and Library Science, (pp. 308-319). Santa Barbara:Greenwood Press. 